\title{
Biochar as Phosphorus Conditioner in Substrate for Brazil Nut (Bertholletia excelsa Humb. \& Bonpl.) Seedling Production in the Central Amazon
}

\author{
João Batista Dias Damaceno ${ }^{1}$, Ana Cecília Nina Lobato ${ }^{1}$, Romildo Torres da Gama ${ }^{1}$, \\ Danielle Monteiro de Oliveira ${ }^{2} \&$ Newton Paulo de Souza Falcão ${ }^{2}$ \\ ${ }^{1}$ Faculty of Agricultural Sciences, Postgraduate Program in Tropical Agronomy, Federal University of \\ Amazonas, Manaus, Brazil \\ ${ }^{2}$ Department of Agronomic Sciences, National Institute of Amazonian Research, Manaus, Brazil \\ Correspondence: João Damaceno, Faculty of Agricultural Sciences, Federal University of Amazonas, Manaus, \\ Amazonas, 69067-005, Brazil. Tel: 55-699-8468-7323. E-mail: joaodiasrm@gmail.com
}

Received: February 9, 2019 Accepted: March 24, 2019 Online Published: May 15, 2019

doi:10.5539/jas.v11n6p383 URL: https://doi.org/10.5539/jas.v11n6p383

\begin{abstract}
The aim of this study was to evaluate the interaction of biochar and phosphorus in substrate for seedling production of Brazil nut. A greenhouse experiment was carried out with the following treatments: five doses of biochar $\left(0,20,40,60\right.$ and $\left.80 \mathrm{tha}^{-1}\right)$ and effect of two levels of phosphorus $\left(0\right.$ and $100 \mathrm{~kg} \mathrm{ha}^{-1}$ of $\left.\mathrm{P}_{2} \mathrm{O}_{5}\right)$ with 4 replicates. The plant height, stem diameter and number of leaves were monthly evaluated. At the end of experiment (180 days), the plants were removed from the pots and were evaluated the dry weight of the seedlings (total, shoot and roots), absolute growth rate, height/diameter and shoot/root ratio, number of leaves, leaf gain and quality index of seedlings. There was a significant interaction between the biochar and phosphorus interaction. The elevation of the bioburden doses did not influence any variables with phosphorus. In the absence of phosphorus, the doses of up to $40 \mathrm{t} \mathrm{ha}^{-1}$ of biochar promoted the highest values of the analyzed variables. Higher doses of biochar $\left(>40 \mathrm{th}^{-1}\right)$ reduced the growth and seedlings quality, however, it was found that under phosphate fertilization, the seedlings were obtained better growth results.
\end{abstract}

Keywords: phosphate fertilization, pyrogenic coal, seedling quality

\section{Introduction}

The current advances of anthropic activities in the Amazon, such as shifting agriculture (cutting and burning), a system of cultivation with low technological level, have contributed to the emergence of degraded land (Ferreira et al., 2015). In order to reduce the productive capacity of the soils (Ferreira et al., 2011), these practices interrupt this process, reducing the productive capacity of the soils (Fearnside \& Leal Filho, 2002, Lima et al., 2015), which results in the search for new areas. In this context, the recovery process of these areas should be initiated with the production of quality seedlings (Souchie et al., 2011), and preferential planting of local species (Chapin, 1980). Native to the brazilian Amazon, Bertholletia excelsa (Brazil Nut), has been used for this purpose, due to its rusticity and good development (Souza et al., 2008). Even for this adapted species, the unfavorable chemical conditions of the Amazonian soils, such as high acidity and low nutrient reserve (Sanches et al., 1982) make it difficult to establish them in planting, making necessary measures to improve soil conditions, especially fertility (Jaquetti et al., 2014).

The low level of phosphorus (P) (1-3 $\left.\mathrm{mg} \mathrm{dm}^{-3}\right)$, the main limiting nutrient in the Amazon region, has been attributed the characteristics of the source material and its strong chemical interaction with soil elements (Raij, 2011). Because of this fact, about $10 \%$ of the applied $\mathrm{P}$ becomes available plants, limiting plant production (Fageria, 2008) and increasing costs with corrections and fertilization (Grant et al., 2001). The rest of the applied $\mathrm{P}$ is unavailable in the form of precipitates with aluminum $(\mathrm{Al})$ and iron $(\mathrm{Fe})$ or adsorbed on the surface of the $\mathrm{Fe}$ and $\mathrm{Al}$ oxides and of the clays, predominating the kaolinite (Meurer, 2010), making the content of P presents high potential for use (Alcarde et al., 1991). It is necessary to use soil conditioners that provide chemical modifications (Petter et al., 2012), in order to have access to the residual P unavailable by such processes (Rheinheimer \& Anghinoni, 2003). 
Several studies have focused on the fact that biochar confers improvements on applied soil, such as increased loads, pH and nutrient availability (Kämpf et al., 2003; Lehmann et al., 2003; Kloss et al., 2014). When it comes to their interaction with $\mathrm{P}$, there are studies showing that their application increases the available P (Atkinson et al., 2010; Deluca et al., 2015), as well as its decrease (Falcão et al., 2003; Yao et al., 2012; Schneider \& Haderlein, 2016), but with inconsistent results. According to Wang et al. (2012), in contact with the soil, the biochar can directly retain cations $\left(\mathrm{Al}^{3+}\right.$ and $\mathrm{Fe}^{3+}$ and $\mathrm{Mn}^{2+}$ ) that precipitate the phosphorus, raising it in solution. Cui et al. (2011) observed that their presence decreases the affinity of the $\mathrm{P}$ in the oxides of Fe, favoring its use and residual effect. DeLuca et al. (2006) concluded that the $\mathrm{pH}$ changes promoted by the addition of biochar to the soil improves the availability of $\mathrm{P}$, since its direct dependence on this factor and Zhang et al. (2016) have warned that both adsorption and desorption of $\mathrm{P}$ may depend on the interaction of soil charges with biochar.

Observed the benefits promoted by the addition of biochar associated with fertilizers in crop development (Steiner et al., 2007; Petter et al., 2012), as well as its recurrent use as part of the substrate of forest seedlings (Souchie et al., 2011; Peter et al., 2012; Lima et al., 2016), the objective of this study was to evaluate the potential of biochar as a soil conditioner, influencing the residual effect of phosphate fertilizer for the production of Brazil Nut seedlings under soil typical of Central Amazon.

\section{Material and Methods}

\subsection{Location and Experimental Design}

The experiment was carried out in a greenhouse of the National Institute of Amazonian Research (INPA),

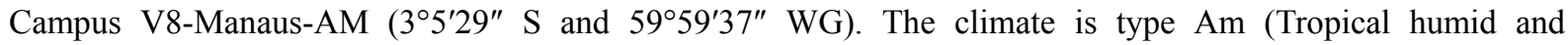
subhumid), with average temperature of $27.4{ }^{\circ} \mathrm{C}$ (Alvares et al., 2014). This experiment was carried out in a temporal sequence to the experiment conducted between December 2014 and December 2015 in the same locality and under the same conditions, where the effect of the biochar and phosphate fertilizer interaction on the growth of Brazil nut seedlings (Bertholletia excelsa). A completely randomized design was used in a factorial scheme $(5 \times 2)$, with five doses of biochar $\left(0,20,40,60\right.$ and $\left.80 \mathrm{t} \mathrm{ha}^{-1}\right)$ equivalent to $0,1,2,3$ and $4 \%$ of the volume $(\mathrm{v} / \mathrm{v})$ and two doses of phosphorus $\left(0\right.$ and $\left.100 \mathrm{~kg} \mathrm{ha}^{-1} \mathrm{P}_{2} \mathrm{O}_{5}\right)$ as triple superphosphate (SFT).

\subsection{Soil and fertilization conditions}

The soil used in the experiment was collected in the subsoil $(20-40 \mathrm{~cm})$ at the INPA experimental station, classified as typical dystrophic Yellow Oxisol and the chemical and physical characteristics are presented in Table 1. The biochar was produced from the meso and exocarpo of urchins of Brazil nut (harvest 2013-2014). In the biocarbonization process, the equipment was used refractory brick pyrolysis furnace (capacity $20 \mathrm{~kg}$ ) of the Pulp and Charcoal Laboratory of the INPA Forest Products Coordination. The carbonization temperature was raised to $500{ }^{\circ} \mathrm{C}$, maintaining for 30 minutes followed by $24 \mathrm{~h}$ cooling after shutdown. Subsequently, the biochar was sieved in a $2.00 \mathrm{~mm}$ mesh, and the material smaller than $2.00 \mathrm{~mm}$ was used to characterize the chemical attributes in the INPA Soils and Plants Thematic Laboratory using a standardized methodology for the analysis of organic material (Embrapa, 2011). The chemical and physical characteristics are shown in Table 1. The biochar was homogenized with the soil in plastic pots with a capacity of $20 \mathrm{~kg}$ together with standard fertilization of $400 \mathrm{Kg} \mathrm{ha}^{-1}$ of $\mathrm{N}$ (Urea), $532.8 \mathrm{~kg} \mathrm{ha}^{-1}$ of $\mathrm{K}_{2} \mathrm{O}$ (Potassium Chloride-KCl) and $80 \mathrm{~kg} \mathrm{ha}^{-1}$ of micronutrients ( $\mathrm{Fe}, \mathrm{Zn}, \mathrm{Cu}, \mathrm{Mn}, \mathrm{B}$ and $\mathrm{Mo}$ ) in the form of FTE BR12 according to the recommendations of Souza et al. (2008). 
Table 1. Chemical and physical characteristics of soil and biochar used in experimentation

\begin{tabular}{|c|c|c|}
\hline Attributes & Soil characteristics & Biochar characteristics \\
\hline $\mathrm{pH}\left(\mathrm{H}_{2} \mathrm{O}\right)$ & 3.90 & 9.00 \\
\hline $\mathrm{N}\left(\mathrm{mg} \mathrm{dm}^{-3} / \mathrm{g} \mathrm{kg}^{-1}\right)$ & - & 7.00 \\
\hline $\mathrm{P}\left(\mathrm{mg} \mathrm{dm}^{-3} / \mathrm{g} \mathrm{kg}^{-1}\right)$ & 0.99 & 0.60 \\
\hline $\mathrm{K}\left(\mathrm{cmol}_{\mathrm{c}} \mathrm{dm}^{-3} / \mathrm{g} \mathrm{kg}^{-1}\right)$ & 0.02 & 23.00 \\
\hline $\mathrm{Ca}\left(\mathrm{cmol}_{\mathrm{c}} \mathrm{dm}^{-3} / \mathrm{g} \mathrm{kg}^{-1}\right)$ & 0.05 & 6.00 \\
\hline $\mathrm{Mg}\left(\mathrm{cmol}_{\mathrm{c}} \mathrm{dm}^{-3} / \mathrm{g} \mathrm{kg}^{-1}\right)$ & 0.08 & 2.40 \\
\hline $\mathrm{S}\left(\mathrm{cmol}_{\mathrm{c}} \mathrm{dm}^{-3} / \mathrm{g} \mathrm{kg}^{-1}\right)$ & - & 1.40 \\
\hline $\mathrm{Fe}\left(\mathrm{mg} \mathrm{dm}^{-3} / \mathrm{mg} \mathrm{kg}^{-1}\right)$ & 254.1 & 575.00 \\
\hline $\mathrm{Zn}\left(\mathrm{mg} \mathrm{dm}^{-3} / \mathrm{mg} \mathrm{kg}^{-1}\right)$ & 1.13 & 25.00 \\
\hline $\mathrm{Mn}\left(\mathrm{mg} \mathrm{dm}-3 / \mathrm{mg} \mathrm{kg}^{-1}\right)$ & 0.57 & 265.00 \\
\hline $\mathrm{Cu}\left(\mathrm{mg} \mathrm{dm}^{-3} / \mathrm{mg} \mathrm{kg}^{-1}\right)$ & - & 28.00 \\
\hline $\mathrm{B}\left(\mathrm{mg} \mathrm{dm}^{-3} / \mathrm{mg} \mathrm{kg}^{-1}\right)$ & - & 41.00 \\
\hline $\mathrm{Al}\left(\mathrm{cmol}_{\mathrm{c}} \mathrm{dm}^{-3}\right)$ & 1.65 & - \\
\hline m (\%) & 85.7 & - \\
\hline $\mathrm{v}(\%)$ & 8.33 & - \\
\hline $\operatorname{CEC}(\mathrm{t})\left(\mathrm{cmol}_{\mathrm{c}} \mathrm{dm}^{-3}\right)$ & 1.05 & - \\
\hline $\mathrm{CEC}(\mathrm{T})\left(\mathrm{cmol}_{\mathrm{c}} \mathrm{dm}^{-3}\right)$ & 1.80 & - \\
\hline Sand $\left(\mathrm{g} \mathrm{kg}^{-1}\right)$ & 432 & - \\
\hline Silt $\left(\mathrm{g} \mathrm{kg}^{-1}\right)$ & 150 & - \\
\hline Clay $\left(\mathrm{g} \mathrm{kg}^{-1}\right)$ & 418 & - \\
\hline
\end{tabular}

\subsection{Obtaining and Preparing Seedlings}

The seedlings of Bertholletia excelsa were ceded by the company Agropecuária Aruanã S. A. (Itacoatiaria-AM) at seven months of age, selecting for vigor and uniformity. The original substrate was removed from the seedlings, transplanting in the form of a "naked root". The seedlings were kept in a greenhouse covered with transparent shingles $(50 \%)$ and $35 \%$ lateral shading screens using manual irrigation (300 $\mathrm{ml} / \mathrm{water} / \mathrm{molt})$. According to the soil analysis, maintenance fertilizations with $\mathrm{N}$ and $\mathrm{K}$ were performed according to the recommendations of Souza et al. (2008). Interventions to control pests or diseases were not necessary. The measurements of collecting diameter (mm), height of the seedlings $(\mathrm{cm})$ and counting of the number of leaves were recorded every 30 days. The diameter was measured using a digital caliper (precision $0.02 \mathrm{~mm}$ ) with a reference of $3.00 \mathrm{~cm}$ from the specimen. The height was measured using a graduated ruler, considering the distance between the collection and the apical bud of the seedlings. The number of leaves was determined by counting the fully expanded leaves.

\subsection{Allometric and Statistical Analysis}

At the end of the experiment (180 days), the seedlings were removed from the substrate by dividing them into shoot and root. The material was washed and was oven driedat $65^{\circ} \mathrm{C}$ for 72 hours. Subsequently, the dry weight of the shoot (DWS), of the roots (DWR) and total (TDW) was determined and calculated the biometric indices: Number of final leaves (NFL); leaf gain (LG) (Equation 1); absolute height growth (AG-H) and diameter (AG-D) (Equation 2); absolute growth rate in height (AGR-H) and diameter (AGR-D) (Equation 3). The height/diameter relation (H/D) was estimated; dry matter ratio (DMAP/DMR) and the Dickson Quality Index (DQI) (Equation 4).

Davanso et al. (2002):

$$
\begin{aligned}
& \mathrm{LG}=(\text { Number of final leaves })-(\text { Initial number of leaves }) \\
\operatorname{AG}\left(\frac{\mathrm{H}}{\mathrm{D}}\right)= & {[\text { Final observation }(\mathrm{cm} \text { or mm })]-[\text { Initial observation }(\mathrm{cm} \text { or } \mathrm{mm})] } \\
& \operatorname{AGR}\left(\frac{\mathrm{H}}{\mathrm{D}}\right)=\frac{[\text { Final observation }(\mathrm{cm} \text { or mm })]-[\text { Initial observation }(\mathrm{cm} \text { or mm })]}{\text { Observation time }}
\end{aligned}
$$

Dickson et al. (1960):

$$
\text { DQI }=\text { TDW }(\mathrm{g}) /[\text { Height }(\mathrm{cm}) / \text { Diameter }(\mathrm{mm})]+\text { DMAP }(\mathrm{g}) / \mathrm{DMR}(\mathrm{g})
$$

The data were submitted to analysis of variance, and the significant means were analyzed by the Tukey test at $5 \%$ of significance, using the statistical program Assistat 7.7 (Silva \& Azevedo, 2016). 


\section{Results and Discussion}

\subsection{Growth in Diameter and Height}

All the growth variables analyzed presented significant responses in at least one of the study factors analyzed and in one of the evaluation periods. Except for final leaves, leaf gain and height/diameter ratio, the other variables were significantly influenced by the biochar and phosphorus interaction (Table 2). In relation to plant height and collection diameter, there was significant interaction only in the last two months of evaluation, 150 and 180 days after transplanting (DAT), respectively.

Table 2. Summary of analysis of variance (F values) for the effects of biochar $\left(B_{c}\right)$ and residual doses of Phosphorus $\left(\mathrm{P}_{\mathrm{res}}\right)$ on the development of young plants of Bertollethia excelsa

\begin{tabular}{|c|c|c|c|c|c|c|c|c|c|c|c|c|}
\hline \multirow{2}{*}{ DAT } & \multicolumn{4}{|c|}{ Height of Plants } & \multicolumn{4}{|c|}{ Diameter of Stem } & \multicolumn{4}{|c|}{ Number of leaves } \\
\hline & $\mathrm{Bc}$ & $\mathrm{P}_{\text {Res }}$ & $\mathrm{Bc}_{\mathrm{x}} \mathrm{P}_{\text {Res }}$ & $\mathrm{CV} \%$ & $\mathrm{Bc}$ & $\mathrm{P}_{\text {Res }}$ & $\mathrm{Bc}_{\mathrm{x}} \mathrm{P}_{\text {Res }}$ & $\mathrm{CV} \%$ & $\mathrm{Bc}$ & $\mathrm{P}_{\text {Res }}$ & $\mathrm{Bc}_{\mathrm{x}} \mathrm{P}_{\text {Res }}$ & $\mathrm{CV} \%$ \\
\hline 30 & $*$ & ns & ns & 11.7 & ns & ns & ns & 10.2 & ns & ns & $\mathrm{ns}$ & 73.8 \\
\hline 60 & $*$ & ns & ns & 11.2 & ns & ns & ns & 9.8 & $*$ & ns & ns & 95.3 \\
\hline 90 & $* *$ & $*$ & ns & 10.1 & ns & ns & ns & 16.0 & $*$ & ns & ns & 80.3 \\
\hline 120 & $* *$ & $*$ & $*$ & 9.7 & $*$ & ns & $*$ & 19.2 & $* *$ & ns & ns & 66.4 \\
\hline 150 & ns & $*$ & $* *$ & 11.0 & $*$ & ns & * & 21.4 & $* *$ & ns & $*$ & 44.6 \\
\hline Var. & $\mathrm{Bc}$ & $P_{\text {Res }}$ & $\mathrm{Bc}_{\mathrm{x}} \mathrm{P}_{\text {Res }}$ & $\mathrm{CV} \%$ & \multicolumn{4}{|c|}{ Var. } & $\mathrm{Bc}$ & $P_{\text {Res }}$ & $\mathrm{Bc}_{\mathrm{x}} \mathrm{P}_{\text {Res }}$ & $\mathrm{CV} \%$ \\
\hline $\mathrm{AG}_{-\mathrm{H}}$ & ns & ns & $*$ & 49.0 & \multicolumn{4}{|c|}{ Height/Diameter Ratio } & $* *$ & ns & ns & 21.5 \\
\hline $\mathrm{AGR}_{-\mathrm{H}}$ & ns & ns & $*$ & 49.0 & \multicolumn{4}{|c|}{ Dry Weight of ShottMatter } & $* *$ & ns & $* *$ & 39.5 \\
\hline $\mathrm{AG}_{-\mathrm{D}}$ & $*$ & ns & $*$ & 50.6 & \multicolumn{4}{|c|}{ Dry Weight of Rroots } & $* *$ & ns & $* *$ & 32.2 \\
\hline $\mathrm{AGR}_{-\mathrm{D}}$ & $*$ & ns & * & 50.6 & \multicolumn{4}{|c|}{ Total Dry Weight } & $* *$ & ns & $* *$ & 34.6 \\
\hline NFL & $* *$ & ns & ns & 23.5 & \multicolumn{4}{|c|}{ Shoot/Root Ratio } & $* *$ & $*$ & $* *$ & 12.2 \\
\hline LG & $* *$ & ns & ns & 38.0 & \multicolumn{4}{|c|}{ Dickson Quality Index } & $* *$ & ns & $* *$ & 43.0 \\
\hline
\end{tabular}

Note. ${ }^{* *}$ and ${ }^{*}$ significant at 1 and $5 \%$ by the Tukey test, respectively; ${ }^{\text {ns }}$ : not significant; Var.: Variables; DAT: days after transplanting; $\mathrm{B}_{\mathrm{c}}$ : Biochar; $\mathrm{P}_{\mathrm{res}}$ : residual phosphorus; $\mathrm{Bc}_{\mathrm{x}} \mathrm{P}_{\mathrm{Res}}$ : Biochar and residual phosphorus interaction; CV: Coefficient of variation; AG-H and AGR-H: Absolute Growth and Absolute Growth Rate for plant height, respectively; $\mathrm{AG}_{-\mathrm{D}}$ and $\mathrm{AGR}_{-\mathrm{D}}$ : Absolute Growth and Absolute Growth Rate for collecting diameter (D), respectively; NFL: Number of final leaves; LG: leaf gain.

The lowest values were observed for the application of the biochar dose $0 \mathrm{~T} \mathrm{ha}^{-1}$, independent of the residual phosphorus, which did not occur for the diameter at the significant periods (Table 3). Although not significant, it is confirmed that phosphorus insufficiency limits plant production (Fageria, 2008), however, according to Glaser et al. (2002) and Petter et al. (2012), the isolated use of biochar does not promote positive effects in the initial phase for forest species, considering that its interaction with mineral fertilizers is beneficial. In the absence of residual phosphorus, the addition of $20 \mathrm{~T} \mathrm{ha}^{-1}$ of biochar promoted greater development in height and diameter. It was found that at higher doses $\left(>20 \mathrm{~T} \mathrm{ha}^{-1}\right)$, the biometric values evaluated in this period were reduced. On the other hand, assuming no significant difference, it was observed that up to $40 \mathrm{~T} \mathrm{ha}^{-1}$ of biochar was increased in height and diameter values with decrease after this dose in the condition of residual phosphorus (Table 3 ). 
Table 3. Plant height, collection diameter, absolute growth and absolute growth rate of young plants of Bertollethia excelsa as a function of the interaction of biochar and residual phosphorus

\begin{tabular}{|c|c|c|c|c|c|c|c|c|}
\hline \multirow{3}{*}{$\mathrm{Bc}\left(\mathrm{T} \mathrm{ha}^{-1}\right)$} & \multirow{2}{*}{\multicolumn{2}{|c|}{$\begin{array}{c}\text { Height }(\mathrm{cm}) 150 \text { DAT } \\
\mathrm{P}_{\text {res }}\left(\mathrm{kg} \mathrm{ha}^{-1} \mathrm{P}_{2} \mathrm{O}_{5}\right)\end{array}$}} & \multirow{2}{*}{\multicolumn{2}{|c|}{$\begin{array}{c}\text { Height }(\mathrm{cm}) 180 \text { DAT } \\
\mathrm{P}_{\text {res }}\left(\mathrm{kg} \mathrm{ha}^{-1} \mathrm{P}_{2} \mathrm{O}_{5}\right)\end{array}$}} & \multirow{2}{*}{\multicolumn{2}{|c|}{$\begin{array}{c}\mathrm{AG}_{-\mathrm{H}}(\mathrm{cm}) \\
\mathrm{P}_{\text {res }}\left(\mathrm{kg} \mathrm{ha}^{-1} \mathrm{P}_{2} \mathrm{O}_{5}\right)\end{array}$}} & \multirow{2}{*}{\multicolumn{2}{|c|}{$\begin{array}{c}\operatorname{AGR}_{-\mathrm{H}}\left(\mathrm{cm} \mathrm{month}^{-1}\right) \\
\mathrm{P}_{\text {res }}\left(\mathrm{kg} \mathrm{ha}^{-1} \mathrm{P}_{2} \mathrm{O}_{5}\right)\end{array}$}} \\
\hline & & & & & & & & \\
\hline & 0 & 100 & 0 & 100 & 0 & 100 & 0 & 100 \\
\hline 0 & $25.05^{\mathrm{bB}}$ & $31.30^{\mathrm{aA}}$ & $27.40^{\mathrm{bB}}$ & $37.03^{\mathrm{aA}}$ & $6.15^{\mathrm{abA}}$ & $11.23^{\mathrm{aA}}$ & $1.02^{\mathrm{abA}}$ & $1.87^{\mathrm{aA}}$ \\
\hline 20 & $37.76^{\mathrm{aA}}$ & $32.50^{\mathrm{aA}}$ & $41.90^{\mathrm{aA}}$ & $34.30^{\mathrm{aB}}$ & $12.13^{\mathrm{aA}}$ & $5.20^{\mathrm{aB}}$ & $2.02^{\mathrm{aA}}$ & $0.86^{\mathrm{aB}}$ \\
\hline 40 & $32.75^{\mathrm{abA}}$ & $36.10^{\mathrm{aA}}$ & $36.90^{\mathrm{abA}}$ & $38.45^{\mathrm{aA}}$ & $8.30^{\mathrm{abA}}$ & $9.60^{\mathrm{aA}}$ & $1.38^{\mathrm{abA}}$ & $1.60^{\mathrm{aA}}$ \\
\hline 60 & $28.45^{\mathrm{bB}}$ & $35.00^{\mathrm{aA}}$ & $30.06^{\mathrm{bB}}$ & $37.05^{\mathrm{aA}}$ & $3.91^{\mathrm{abA}}$ & $4.25^{\mathrm{aA}}$ & $0.65^{\mathrm{abA}}$ & $0.70^{\mathrm{aA}}$ \\
\hline 80 & $31.65^{\mathrm{abA}}$ & $34.20^{\mathrm{aA}}$ & $32.00^{\mathrm{bB}}$ & $39.15^{\mathrm{aA}}$ & $1.65^{\mathrm{bB}}$ & $9.70^{\mathrm{aA}}$ & $0.27^{\mathrm{bB}}$ & $1.61^{\mathrm{aA}}$ \\
\hline S.M.D. & 6.656 & & 5.413 & & 6.025 & & 0.253 & \\
\hline S.M.D. ${ }^{\mathrm{C}}$ & 9.567 & & 7.780 & & 8.659 & & 0.364 & \\
\hline \multirow{3}{*}{$\mathrm{Bc}\left(\mathrm{T} \mathrm{ha}^{-1}\right)$} & \multicolumn{2}{|c|}{ Diameter $(\mathrm{mm}) 150$ DAT } & \multicolumn{2}{|c|}{ Diameter $(\mathrm{mm}) 180$ DAT } & \multicolumn{2}{|c|}{$\mathrm{AG}_{-\mathrm{D}}(\mathrm{mm})$} & \multicolumn{2}{|c|}{$\mathrm{AGR}_{-\mathrm{D}}\left(\mathrm{mm}\right.$ month $\left.^{-1}\right)$} \\
\hline & \multicolumn{2}{|c|}{$\mathrm{P}_{\text {res }}\left(\mathrm{kg} \mathrm{ha}^{-1} \mathrm{P}_{2} \mathrm{O}_{5}\right)$} & \multicolumn{2}{|c|}{$\mathrm{P}_{\text {res }}\left(\mathrm{kg} \mathrm{ha}^{-1} \mathrm{P}_{2} \mathrm{O}_{5}\right)$} & \multicolumn{2}{|c|}{$\mathrm{P}_{\text {res }}\left(\mathrm{kg} \mathrm{ha}^{-1} \mathrm{P}_{2} \mathrm{O}_{5}\right)$} & \multicolumn{2}{|c|}{$\mathrm{P}_{\text {res }}\left(\mathrm{kg} \mathrm{ha}^{-1} \mathrm{P}_{2} \mathrm{O}_{5}\right)$} \\
\hline & 0 & 100 & 0 & 100 & 0 & 100 & 0 & 100 \\
\hline 0 & $3.20^{\mathrm{abA}}$ & $4.01^{\mathrm{aA}}$ & $4.18^{\mathrm{abA}}$ & $4.51^{\mathrm{aA}}$ & $2.23^{\mathrm{abcA}}$ & $2.29^{\mathrm{aA}}$ & $0.37^{\mathrm{abcA}}$ & $0.38^{\mathrm{aA}}$ \\
\hline 20 & $4.42^{\mathrm{aA}}$ & $2.96^{\mathrm{aB}}$ & $5.50^{\mathrm{aA}}$ & $3.07^{\mathrm{aB}}$ & $3.54^{\mathrm{aA}}$ & $0.99^{\mathrm{aB}}$ & $059^{\mathrm{aA}}$ & $0.16^{\mathrm{aB}}$ \\
\hline 40 & $3.75^{\mathrm{abA}}$ & $3.91^{\mathrm{aA}}$ & $4.54^{\mathrm{abA}}$ & $4.18^{\mathrm{aA}}$ & $2.68^{\mathrm{abA}}$ & $2.04^{\mathrm{aA}}$ & $0.44^{\mathrm{abA}}$ & $0.34^{\mathrm{aA}}$ \\
\hline 60 & $2.39^{\mathrm{bA}}$ & $3.25^{\mathrm{aA}}$ & $2.54^{\mathrm{bA}}$ & $3.82^{\mathrm{aA}}$ & $0.44^{\mathrm{cA}}$ & $1.81^{\mathrm{aA}}$ & $0.07^{\mathrm{cA}}$ & $0.30^{\mathrm{aA}}$ \\
\hline 80 & $2.36^{\mathrm{bA}}$ & $3.09^{\mathrm{aA}}$ & $2.76^{\mathrm{bA}}$ & $3.20^{\mathrm{aA}}$ & $0.62^{\mathrm{bcA}}$ & $0.98^{\mathrm{aA}}$ & $0.10^{\mathrm{bcA}}$ & $0.16^{\mathrm{aA}}$ \\
\hline S.M.D. & 1.094 & & 1.402 & & 1.521 & & 1.004 & \\
\hline S.M.D. ${ }^{\mathrm{C}}$ & 1.572 & & 2.016 & & 2.187 & & 1.443 & \\
\hline \multirow{3}{*}{$\mathrm{Bc}\left(\mathrm{T} \mathrm{ha}^{-1}\right)$} & \multicolumn{2}{|c|}{$\mathrm{N}^{\circ}$ of sheets (180 DAT) } & \multicolumn{2}{|c|}{ Number of final leaves } & \multicolumn{2}{|c|}{ Leaf Gain } & \multicolumn{2}{|c|}{ Height/Diameter Ratio } \\
\hline & \multicolumn{2}{|c|}{$\mathrm{P}_{\text {res }}\left(\mathrm{kg} \mathrm{ha}^{-1}\right.$ de $\left.\mathrm{P}_{2} \mathrm{O}_{5}\right)$} & \multirow{2}{*}{\multicolumn{2}{|c|}{$\mathrm{Bc}\left(\mathrm{T} \mathrm{ha}^{-1}\right)$}} & \multirow{2}{*}{\multicolumn{2}{|c|}{$\mathrm{Bc}\left(\mathrm{T} \mathrm{ha}^{-1}\right)$}} & \multirow{2}{*}{\multicolumn{2}{|c|}{$\mathrm{Bc}\left(\mathrm{t} \mathrm{ha}^{-1}\right)$}} \\
\hline & 0 & 100 & & & & & & \\
\hline 0 & $2.66^{\mathrm{abA}}$ & $2.33^{\mathrm{aA}}$ & \multicolumn{2}{|l|}{$11.50^{\mathrm{ab}}$} & \multicolumn{2}{|l|}{$8.33^{\mathrm{ab}}$} & \multicolumn{2}{|l|}{$7.34^{b}$} \\
\hline 20 & $3.00^{\mathrm{aA}}$ & $1.00^{\mathrm{aB}}$ & \multicolumn{2}{|l|}{$14.33^{a b}$} & \multicolumn{2}{|l|}{$9.33^{\mathrm{a}}$} & \multicolumn{2}{|l|}{$9.87^{\mathrm{ab}}$} \\
\hline 40 & $3.00^{\mathrm{aA}}$ & $2.33^{\mathrm{aA}}$ & \multicolumn{2}{|l|}{$15.83^{\mathrm{a}}$} & $10.83^{\mathrm{a}}$ & & $8.84^{\mathrm{ab}}$ & \\
\hline 60 & $0.00^{\mathrm{cA}}$ & $1.00^{\mathrm{aA}}$ & $9.83^{b}$ & & $3.33^{c}$ & & $10.98^{a b}$ & \\
\hline 80 & $1.00^{\mathrm{bcA}}$ & $1.00^{\mathrm{aA}}$ & $9.83^{b}$ & & $3.83^{b c}$ & & $12.47^{\mathrm{a}}$ & \\
\hline S.M.D. & 1.896 & & - & & - & & - & \\
\hline S.M.D. ${ }^{\mathrm{C}}$ & 1.319 & & 5.006 & & 4.698 & & 3.694 & \\
\hline
\end{tabular}

Note. The averages followed by the same upper and lower case letters in the rows do not differ statistically from each other by the Tukey test at $5 \%$ probabilit; Bc: biochar; $\mathrm{P}_{\text {res }}$ : fósforo residual; $\mathrm{Bc}^{\mathrm{x}} \mathrm{P}^{\mathrm{Res}}$ : $\mathrm{AG}_{-\mathrm{H}}$ and $\mathrm{AGR}_{-\mathrm{H}}$ : Absolute Growth and Absolute Growth Rate for plant height, respectively; $\mathrm{AG}_{-\mathrm{D}}$ and $\mathrm{AGR}_{-\mathrm{D}}$ : Absolute Growth and Absolute Growth Rate for collecting diameter (D), respectively. S.M.D. : Significant Minimum Difference in lines; S.M.D. ${ }^{\text {C }}$ : Minimal Significant Difference in the columns.

The observed data corroborate with those obtained by Zanetti et al. (2003), where they found that lower concentrations of biochar resulted in higher values for height and diameter in leaflets of Citrus limbus (Citrus limonia). The lack of proportionality with the increase of biochar doses were also observed by Rezende et al. (2016) in the composition of substrates for Teca seedlings (Tectona grandis), suggesting that increasing doses interfere in the macroporosity of the substrate, hindering the development of the plants.

For fixed doses of $100 \mathrm{mg} \mathrm{dm}^{-3}$ of phosphorus, Lima et al. (2016) did not observe differences in height and diameter in angico (Anadenanthera colubrina) seedlings after 120 days of planting, with concentrations of biochar varying from 0 to $35 \%$. The behavior of the diameter are in agreement with those obtained by Simões et al. (2015), which obtained in Brazil Nut seedlings higher values in the absence of substrate fertilization (4.87 $\mathrm{mm})$ followed by isolated fertilization of $\mathrm{P}(4.55 \mathrm{~mm})$ at 150 DAT. Absolute growth and absolute growth rate in height and diameter were positively influenced $(\mathrm{P}<0.05)$ by the addition of up to $40 \mathrm{~T} \mathrm{ha}^{-1}$ of biochar in the absence of residual phosphorus. The values observed for the interaction with residual phosphate fertilization were not significant in any of these parameters. The data corroborate with Correa (2013), who verified mean TCA-D of $0.59 \mathrm{~mm} \mathrm{month}^{-1}$ in the absence of $\mathrm{P}$ in Brazil nut tree seedlings after eight months of observation. 
Under phosphate fertilization, Ferreira et al. (2012) did not observe significant differences in these parameters for the same species in the same evaluation period.

The number of leaves was significant for the biochar and residual phosphorus interaction in the last month of evaluation (180 DAT). In the presence of residual phosphorus, no gains were observed with increasing doses of biochar; however, up to $40 \mathrm{~T} \mathrm{ha}^{-1}$, a higher number of leaves was obtained in the absence of phosphorus. According to Taiz and Zeiger (2004), the number of leaves may reflect the other morphological variables analyzed, such as height, diameter and increment of dry matter, a fact confirmed in this study. It was observed that the number of leaves and foliar gain were significantly increased until the addition of $40 \mathrm{~T} \mathrm{ha}^{-1}$ of biochar, demonstrating depressive behavior at the highest doses, represented by the equations $y=-0,0.0024 x^{2}+0.1488 x$ $+11.952\left(R_{2}=0.6295\right)$ and $y=-0.0018 x^{2}+0.0679 x+8.7014\left(R_{2}=0.6544\right)$. It was verified by Souchie et al. (2011), that higher doses of biochar improved substrate moisture conditions, promoting a higher average increase of carvoeiro (Tachigali vulgaris) seedlings, differing from the results found in this work.

\subsection{Leaf Production and Dry Matter}

The height/diameter ratio was proportionally influenced by the increase of biochar doses $(y=0.0569+7.626$ and $\mathrm{R}_{2}=0.8368$ ), but not significant for the interaction with residual phosphorus (Table 2). According to Bircherl et al. (1998), this relation must be below 10 in forest seedlings because it expresses the growth balance of these variables. Up to the $40 \mathrm{~T} \mathrm{ha}^{-1}$ dose of biochar, values below this threshold were observed, but above, higher than desirable ratios were obtained, 10.98 and 12.47, respectively (Table 2). According to Cruz et al. (2006), lower values of this parameter reflect a greater capacity of survival of the field seedlings, as observed for the doses of 0 $\mathrm{T} \mathrm{ha}^{-1}$ of biochar (7.34), whereas for Brazil nut tree seedlings there is no recommended ratio, as for pinus (Pinus taeda), between 5.4 and 8.1 (Carneiro, 1995) and paricá (Schizolobium amazonicum), between 8.77 and 9.48 (Caione et al., 2012).

The addition of biochar to the substrate significantly influenced seedling dry matter production of Brazil Nut. Regarding dry matter of shoot and roots, submitted to the absence of residual phosphorus, the biochar doses of $20 \mathrm{~T} \mathrm{ha}^{-1}$ and $40 \mathrm{~T} \mathrm{ha}^{-1}$ promoted the best values significant and superior to those observed by seedlings supplied previous phosphate fertilization. However, doses above $40 \mathrm{~T} \mathrm{ha}^{-1}$ and non-application provided decreases in these variables. There was no significance for these variables when submitted to fixed dose of residual phosphorus, regardless of the dose of biochar applied (Figures 1 and 2). The higher values observed for dry matter of the roots compared to the shoot can reveal low availability of (Khamis et al., 1990).

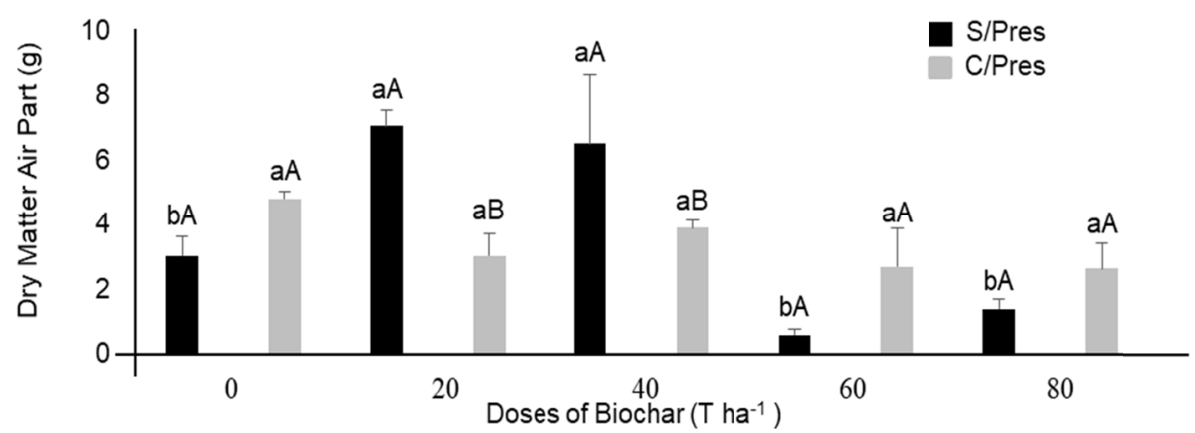

Figure 1. Dry matter Air Part \pm standard deviation of Berthollethia excelsa seedlings, six months after transplanting under different doses of biochar in the substrate in the absence and presence of residual phosphorus. Means followed by the same lowercase letters and upper case letters between treatments do not differ statistically from each other by the tukey test $5 \%$ probability. S/Pres: Absence of residual phosphorus; C/Pres: Presence of residual phosphorus 


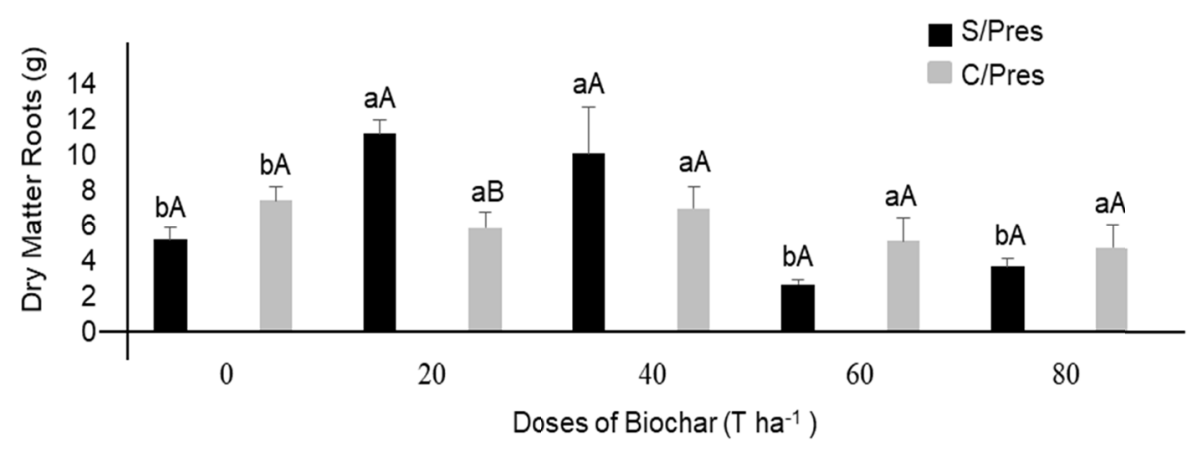

Figure 2. Root dry matter \pm standard deviation of Berthollethia excelsa seedlings, six months after transplanting under different doses of biochar in the substrate in the absence and presence of residual phosphorus. Means followed by the same lowercase letters and upper case letters between treatments do not differ statistically from each other by the tukey test $5 \%$ probability. S/Pres: Absence of residual phosphorus; C/Pres: Presence of residual phosphorus

The results obtained are compatible with those obtained by Petter et al. (2012), who did not verify dry matter gains of these parts proportional to the increase of biochar concentrations in the substrate for the formation of eucalyptus seedlings, already Lima et al. (2016) did not observe differences in the concentrations of biochar studied $(0 \%, 5 \%, 10 \% 20 \%$ and $35 \%)$ in angico seedlings in the absence $\left(0 \mathrm{mg} \mathrm{dm}^{-3} \mathrm{P}\right)$ or presence of phosphorus (100 $\mathrm{mg} \mathrm{dm}^{-3} \mathrm{P}$ ). In Brazil Nut seedlings at 210 days of planting, Nunes (2010), analyzing different concentrations of biochar to the substrate $(0 \%, 10 \%, 30 \%, 50 \%$ and $70 \%)$, verified that both shoot and root dry matter were favored by intermediate concentrations (30 and 50\%) in clay soil.

For the total dry matter, the observed behavior was similar to that observed for the isolated dry matter results, in which intermediate doses of biochar favored the biomass production in the chestnut seedlings in the absence of residual phosphorus, however, no significant gains were verified with the increase of available phosphorus (Figure 3). The data on the production of total dry matter in those fed with phosphorus corroborate with results found by Simões et al. (2015) and Caione et al. (2012), who verified that in the Amazonian species Bertholletia excelsa and Schizolobium amazonicum, respectively, fertilization with NPK and P alone promoted the best results for this variable. The results also resemble those obtained by Lima et al. (2000), where they found that the combination of biochar + source of mineral fertilizer were more effective in the production of dry matter in Tingui do Cerrado (Magonia pubescens) seedlings.

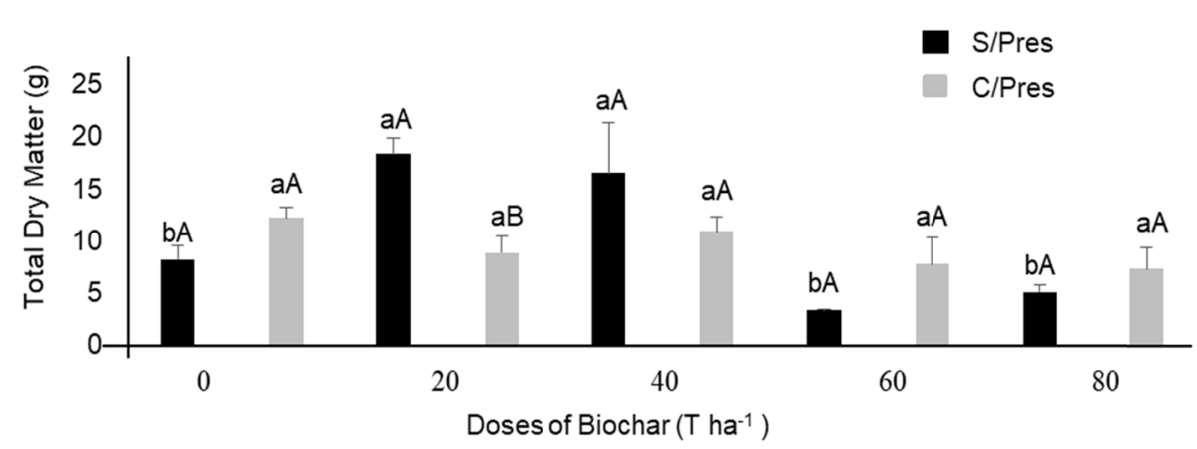

Figure 3. Total dry matter \pm standard deviation of Berthollethia excelsa seedlings, six months after transplanting under different doses of biochar in the substrate in the absence and presence of residual phosphorus. Means followed by the same lowercase letters and upper case letters between treatments do not differ statistically from each other by the tukey test $5 \%$ probability. S/Pres: Absence of residual phosphorus; C/Pres: Presence of residual phosphorus

\subsection{Dickson Quality and Allometric Relationships}

There was no significant difference between the doses of biochar for the shoot dry matter/root ratio in the presence of residual phosphorus, however, doses of up to $40 \mathrm{~T} \mathrm{ha}^{-1}$ promoted the highest observed values, 0.587 , 0.640 and 0.648 , respectively in the absence of phosphorus. Values below 1 reflect the higher development of 
shoot roots in relation to aerial part, however, the higher the expression of lower quality seedlings, the lower values can guarantee the highest seedling survival in the field (Gomes et al., 2004). For Eucalyptus (Eucalyptus citriodora) seedlings, Petter et al. (2012) attributed the highest values as a preparation mechanism for adverse conditions, such as nutrient and water limitation, a fact that provides greater accumulations of biomass of the aerial stop, increasing the relation.

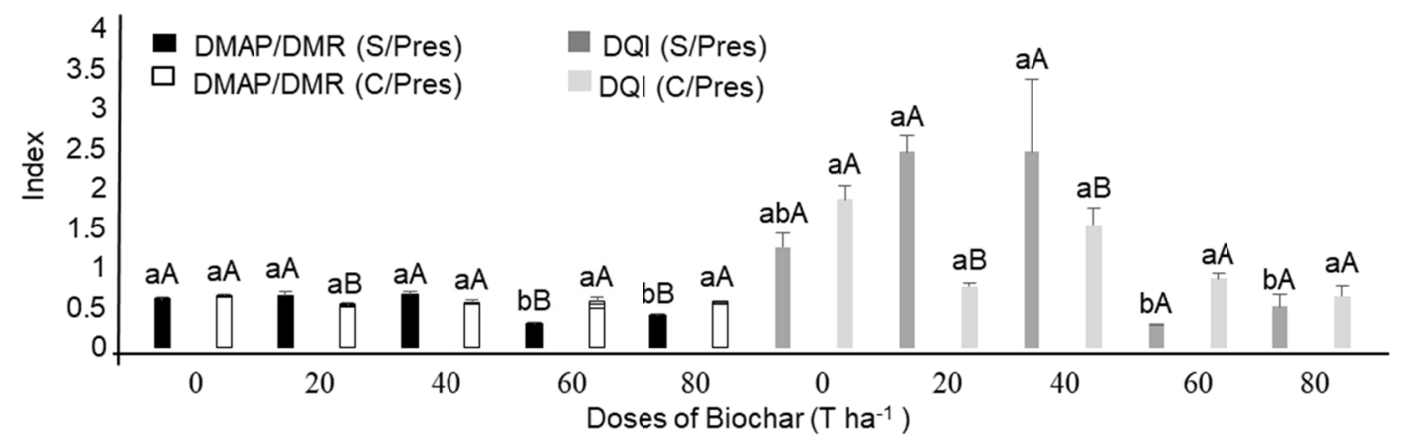

Figure 4. Dry matter air part ratio (DMAP) and root dry matter (DMR) and Dickson Quality Index (DQI) \pm standard deviation of seedlings of Berthollethia excelsa, six months after transplanting under different doses of

biochar in the substrate in the absence and Presence of residual phosphorus. Means followed by the same lowercase letters and upper case letters between treatments do not differ statistically from each other by the tukey test 5\% probability. S/Pres: Absence of residual phosphorus; C/Pres: Presence of residual phosphorus

According to Fonseca et al. (2002), Dickson's quality index is more accurate than the analysis of isolated factors, considering robustness and balance in the evaluation. The values found for this index in the presence of residual

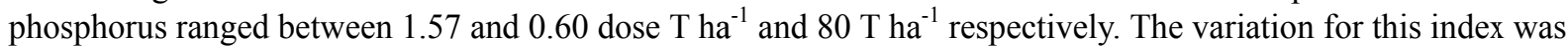
also observed by Simões et al. (2015) under the presence of P in Brazil Nut seedlings at 150 days after planting promoted by differences in the growth and biomass variables that compose the calculation, which may be related to the nutrient reserve present in almonds (Santos et al., 2013). However, there is no significant difference in the interaction of biochar with fertilizer or substrate composition in the production of forest seedlings (Freitas et al., 2004), while others (Petter et al., 2012; Rezende et al., 2016), have identified that the increase of the doses of biochar promotes better quality indices.

\section{Conclusions}

Regardless of the dose of biochar applied in the presence of residual phosphorus, the variables for height, diameter, number of leaves, shoot dry matter, roots and total did not show significant differences between them. In the absence of residual phosphorus, mean doses $\left(20 \mathrm{~T} \mathrm{ha}^{-1}\right.$ and $\left.40 \mathrm{~T} \mathrm{ha}^{-1}\right)$ provided the highest significant values in these variables, while as the non-application of biochar provided the lowest values. The absolute growth and growth rate in height and diameters followed the same behavior presented.

The number of leaves, leaf gain and height/diameter ratio were significantly influenced only by the addition of biochar, the latter being proportional to the increase of the doses, a fact inversely observed for the final leaves. Intermediate doses of $20 \mathrm{~T} \mathrm{ha}^{-1}$ and $40 \mathrm{~T} \mathrm{ha}^{-1}$ of biochar favored leaf gain. The quality index of Dickson was proportionally high with increasing doses of biochar (up to $40 \mathrm{~T} \mathrm{ha}^{-1}$ ) in the absence of residual phosphorus, with decreases occurring thereafter. In the presence of phosphorus, doses above $40 \mathrm{~T} \mathrm{ha}^{-1}$ decreased the quality of the seedlings, but without significance.

\section{References}

Alcarde, J. C., Guindolin, J. A., \& Lopes, A. S. (1991). Os Adubos e a eficiência das adubações (2nd ed.). São Paulo: ANDA.

Alvares, C. A., Stape, J. L., Sentelhas, P. C., Gonçalves, J. L. M., \& Sparovek, G. (2014) Köppen’s climate classification map for Brazil. Meteorologische Zeitschrift, 22(6), 711-728. https://doi.org/10.1127/09412948/2013/0507

Atkinson, C. J., Fitzgerald, J. D., \& Hipps, N. (2010). Potential mechanisms for achieving agricultural benefits from biochar application to temperate soils: A review. Plant and Soil, 337(2), 1-18. https://doi.org/ 10.1007/s11104-010-0464-5 
Birchler, T., Rose, R. W., Royom, A., \& Pardos, M. (1998). La planta ideal: Revisión del concepto, parámetros definitorios e implementación práctica. Investigación Agraria: Sistemas y Recursos Forestales, 7(2), 109-121.

Caione, G., Lange, A., \& Schoninger, E. L. (2012). Crescimento de mudas de Schizolobium amazonicum em substrato fertilizado com nitrogênio, fósforo e potássio. Scientia Forestalis, 40(94), 213-221.

Carneiro, J. G. A. (1980). Produção e controle de qualidade de mudas florestais. Curitiba: UFPR.

Chapin, F. S. (1980). The mineral nutrition of wild plants. Annual Review of Ecology and Systematics, 11(1), 233-260. https://doi.org/10.1146/annurev.es.11.110180.001313

Corrêa, V. M. (2013). Crescimento, aspectos nutricionais e fotossintéticos de plantas jovens de Bertholletia excelsa H. B. Submetidas à diferentes tratamentos de fertilização (Master's thesis, National Research Institute of the Amazon, Manaus, Amazonas). Retrieved from https://bdtd.inpa.gov.br/

Cruz, C. A. F., Paiva, H. N., \& Guerrero, C. R. A. (2006). Efeito da adubação nitrogenada na produção de mudas de sete-cacas (Samanea inopinata (Harms) Ducke). Revista Árvore, 30(4), 537-546. https://doi.org/ 10.1590/S0100-67622006000400006

Cui, H. J., Wang, M. K., Fu, M. L., \& Ci, E. (2011). Enhancing phosphorus availability in phosphorus-fertilized zones by reducing phosphate adsorbed on ferrihydrite using rice straw-derived biochar. Journal of Soils Sediments, 11(1), 1135-1174. https://doi.org/10.1007/s11368-011-0405-9

Davanso, V. M., Souza, L. A., Medri, M. E., Pimenta, J. A., \& Bianchini, E. (2002). Photosynthesis, growth and development of Tabebuia avellanedae Lor. Ex Griseb. (Bignoniaceae) in flooded soil. Brazilian archives of Biology and Technology, 45(3), 375-384. https://doi.org/10.1590/S1516-89132002000300016

Deluca, T. H., Mackenzie, M. D., \& Gundale, M. J. (2015). Biochar effects on soil nutriente transformations. In J. Lehmann, \& S. Joseph (Eds.), Biochar for environmental management: Science, Technology and Implementation (2nd ed.). New York: Taylor and Francis.

Dickson, A., Leaf, A. L., \& Hosner, J. F. (1960). Quality appraisal of white spruce and white pine seedling stock in nurseries. Forest Chronicle, 36(1), 10-13. https://doi.org/10.5558/tfc36010-1

Embrapa. (2011). Manual de análises químicas de solos, plantas e fertilizantes (1st ed.). Brasília: Embrapa.

Fageria, N. K. (2008). The use of nutrients in crop plants. New York: CRC Press. https://doi.org/10.1201/ 9781420075113

Falcão, N. P. S., Comerford, N., \& Lehmann, J. (2003). Determining nutrient bioavailability of Amazonian Dark Earth soils, methodological challenges. In J. Lehmann, D. C. Kern, B. Glaser, \& W. I. Woods (Eds.), Amazonian Dark Earths: Origin, Properties, Managements. Dordrecht: Kluwer. https://doi.org/10.1007/ 1-4020-2597-1_14

Fearnside, P. M., \& Leal Filho, N. (2002). Solo e desenvolvimento na Amazônia: Lições do projeto dinâmica biológica de fragmentos florestais. Manaus: INPA.

Ferreira, M. J., Gonçalves, J. F. C., \& Ferraz, J. B. S. (2012). Crescimento e eficiência do uso da água de plantas jovens de Castanheira-da-Amazônia em área degradada e submetida à adubação. Ciência Florestal, 22(2), 393-401. https://doi.org/10.5902/198050985747

Ferreira, M. J., Gonçalves, J. F. C., Ferraz, J. B. S., \& Corrêa, V. M. (2015). Características nutricionais de plantas jovens de Bertholletia excelsa Bonpl. sob tratamentos de fertilização em área degradada na Amazônia. Scientia Florestalis, 43(108), 863-872. https://doi.org/10.18671/scifor.v43n108.11

Fonseca, E. P., Valéri, S. V., Miglioranza, E., Fonseca, N. A. N., \& Couto, L. (2002). Padrão de qualidade de mudas de Trema micrantha (L.) Blume produzidas sob diferentes períodos de sombreamento. Revista Árvore, 26(4), 515-523. https://doi.org/10.1590/S0100-67622002000400015

Freitas, A. F., Souza, L. A. G., Cardoso, I. M., \& Paiva, H. N. (2014). Fino de carvão vegetal em substrato para produção de mudas de Dipteryx odorata. Revista Brasileira de Agroecologia, 9(3), 31-40.

Glaser, B., Lehmann, J., \& Zech, W. (2002). Ameliorating physical and chemical properties of highly weathered soils in the tropics with charcoal-A review. Biology and Fertility of Soils, 35(4), 219-230. https://doi.org/ 10.1007/s00374-002-0466-4 
Gomes, K. C. O., Paiva, H. N., Neves, J. C. L., Barros, N. F., \& Silva, S. R. (2004). Influência da saturação por bases e do fósforo no crescimento de mudas de angico branco. Revista Árvore, 28(6), 785-792. https://doi.org/10.1590/S0100-67622004000600003

Grant, C. A., Flaten, D. N., Tomasiewicz, D. J., \& Sheppard, S. C. (2001). A importância do fósforo no desenvolvimento inicial da planta. Piracicaba: Potafos.

Jaquetti, R. K., Gonçalves, J. F. C., Ferraz, J. B. S, Ferreira, M. J., Santos, U. M., \& Lacerda, C. F. (2014). Green fertilization enhances the photosynthetic performance and the growth of leguminous trees forrestoration plantation in central Amazon. American Journal of Plant Sciences, 5(16), 2497-2508. https://doi.org/ 10.4236/ajps.2014.516264

Kämpf, N., Sombroek, W., Woods, W. I., \& Cunha, T. J. F. (2003). Classification of Amazonian Dark Earths in the Brazilian Amazon. In J. Lehmann, D. C. Kern, B. Glaser, \& W. I. Woods (Eds.), Amazonian Dark Earths: Origin, Properties, Management. Dordrecht: Kluwer.

Khamis, S., Chaillou, S., \& Lamaze, T. (1990). $\mathrm{CO}_{2}$ assimilation and partitioning of carbon in maize plants deprived of orthophosphate. Journal of Experimental Botany, 41(12), 1619-1625. https://oi.org/10.1093/ jxb/41.12.1619

Kloss, S., Zehetner, F., Wimmer, B., Buecker, J., Rempt, F., \& Soja, G. (2014). Biochar application to temperate soils: Effects on soil fertility and crop growth under greenhouse conditions. Journal of Plant Nutrition and Soil Science, 177(1), 3-15. https://doi.org/10.1002/jpln.201200282

Lehmann, J. (2007). Bio-energy in theblack. Frontiers in Ecology and the Environment, 5(7), $381-387$. https://doi.org/10.1890/1540-9295

Lehmann, J., Silva, J. P., Steiner, C., Nehls, T., Zech, W., \& Glaser, B. (2003). Nutrient availability and leaching in an archaeological Anthrosol and a Ferralsol of the Central Amazon basin: Fertilizer, manure and charcoal amendments. Plant and Soil, 249(2), 343-357. https://doi.org/10.1023/A:1022833116184

Lima, S. L., Junior, B. H. M., Santos, K. S. M., Reis, S. M., Petter, F. A., Vilar, C. C., \& Marimon, B. S. (2016). Biochar no manjo de nitrogênio e fósforo para produção de mudas de angico. Pesquisa Agropecuária Brasileira, 51(2), 120-131. https://doi.org/10.1590/S0100-204X2016000200004

Lima, S. L., Tamiozzo, S., Palomino, E. C., Petter, F. A., \& Junior, B. H. M. (2015). Interactions of biochar and organic compound for seedlings production of Magonia pubescens A. St. Hil. Revista Árvore, 39(4), 655-661. https://doi.org/10.1590/0100-67622015000400007

Lima, S. S., Leite, L. F. C., Oliveira, F. C., \& Costa, D. B. (2011). Atributos químicos e estoques de carbono e nitrogênio em Argissolo Vermelho-amarelo sob sistemas agroflorestais e agricultura de corte e queima no norte do Piauí. Revista Árvore, 35(1), 51-60. https://doi.org/10.1590/S0100-67622011000100006

Meurer, E. J. (2010). Fundamentos de química do solo (4th ed.). Porto Alegre: Evangraf.

Mukome, F. N. D., Zhang, X., Silva, L. C. R., Six, J., \& Parikh, S. (2013). Use of chemical and physical characteristics to investigate trends in biochar feedstocks. Journal of Agricultural and Food Chemistry, 61(9), 2196-2204. https://pubs.acs.org/doi/abs/10.1021/jf3049142

Nunes, M. M. (2010). Carvão vegetal como componente de substrato para produção de mudas de Castanheira-do-brasil (Bertholletia excelsa Bonpl.) (Master's thesis, Federal University of Amazonas, Manaus, Amazonas). Retrieved from https://tede.ufam.edu.br

Petter, F. A., Madari, B. E., Silva, M. A. S., Carneiro, M. A. C., Carvalho, M. T. M., Junior, B. H. M., \& Pacheco, L. P. (2012). Soil fertility and upland rice yield after biochar application in the Cerrado. Pesquisa Agropecuária Brasileira, 47(5), 699-706. https://doi.org/10.1590/S0100-204X2012000500010

Raij, B. V. (2011). Fertilidade do solo e manejo de nutrientes. Piracicaba: International Plant Nutrition Institute.

Rezende, F. A., Santos, V. A. H. F., Maia, C. M. B. F., \& Morales, M. M. (2016). Biochar na composição de substratos para a produção de mudas de teca. Pesquisa Agropecuária Brasileira, 51(9), 1449-1456. https://doi.org/10.1590/s0100-204x2016000900043

Rheinheimer, D. S., \& Anghinoni, I. (2003). Accumulation of soil organic phosphorus by soil tillage and cropping systems in subtropical soils. Communications in Soil Science and Plant Analysis, 23(15), 2339-2354. https://doi.org/10.1081/CSS-120024068 
Sanchez, P. A., Bandy, D. E., Villachica, J. H., \& Nichlaides, J. J. (1982). Amazon basin soils: Management for continuous crop production. Science, 216(4548), 821-827. https://doi.org/10.1126/science.216.4548.821

Santos, S. C., Venturin, N., Teixeira, G. C., Carlos, L., \& Macedo, R. L. G. (2013). Avaliação da qualidade de mudas de castanha-do-brasil submetidas à ausência de nutrientes. Enciclopédia Biosfera, 9(16), 439-450.

Schneider, F., \& Haderlein, S. B. (2016). Potential effects of biochar on the availability of phosphorusmechanistic insights. Geoderma, 277(1), 83-90. https://doi.org/10.1016/j.geoderma.2016.05.007

Silva, F. A. Z., \& Azevedo, C. A. V. (2016). The Assistat Software Version 7.7 and its use in the analysis of experimental data. African Journal of Agricultural Research, 39(11), 3733-3740.

Simões, P. H. O., Palheta, L. F., Vale, R. S., Correia, R. G., \& Neves, R. L. P. (2015). Crescimento e qualidade de mudas de Castanheira-do-brasil (Bertholletia excelsa Bonpl. Lecythidaceae) em substratos fertilizados com macronutrientes. Enciclopédia Biosfera, 11(21), 689-703.

Souchie, F. F., Junior, B. H. M., Petter, F. A., Madari, B. E., Marimon, B. S., \& Lenza, E. (2011). Carvão pirogênico como condicionante para substrato de mudas de Tachigali vulgaris. Ciência Florestal, 21(4), 811-821. https://doi.org/10.5902/198050984526

Souza, C. R., Azevedo, C. P., Rossi, L. M. B., \& Lima, R. M. B. (2008). Castanha-do-Brasil (Bertholletia excelsa Humb. \& Bonpl.). Manaus: Embrapa Amazônia Ocidental. Retrieved from https://www.infoteca. cnptia.embrapa.br/bitstream/doc/669639/1/ComTec632008.pdf

Steiner, C., Teixeira, W. G., Lehmann, J., Nehls, T., Macedo, J. L. V., Blum, W. E. H., \& Zech, W. (2007). Long term effects of manure, charcoal and mineral fertilization on crop production and fertility on a highly weathered Central Amazonian upland soil. Plant and Soil, 291(2), 275-290. https://doi.org/10.1007/s11104007-9193-9

Taiz, L., \& Zeiger, E. (2004). Fisiologia vegetal (3rd ed.). Porto Alegre: Artmed.

Wang, T., Arbestain, M. C., Hedley, M., \& Bishop, P. (2012). Predicting phosphorus bioavailability from high-ash biochars. Plant and Soil, 357(2), 173-187. https://doi.org/10.1007/s11104-012-1131-9

Yao, Y., Gao, B., Zhang, M., Inyang, M., \& Zimmerman, A. R. (2012). Effect of biochar amendmen on sorption and leaching of nitrate, ammonium, and phosphate in a sandy soil. Chemosphere, 89(11), 1467-1471. https://doi.org/10.1016/j.chemosphere.2012.06.002

Zanetti, M., Cazetta, J. O., Junior, D. M., \& Carvalho, A. S. (2003). Uso de subprodutos de carvão vegetal na formação do porta-enxerto limoeiro "cravo" em ambiente protegido. Revista Brasileira Fruticultura, 25(3), 508-512. https://doi.org/10.1590/S0100-29452003000300037

Zhang, H., Chen, C., Gray, E. M., Boyd, S. E., Yang, H., \& Zhang, D. (2016). Roles of biochar in improving phosphorus availability in soils: A phosphate adsorbent and a source of available phosphorus. Geoderma, 276(15), 1-6. https://doi.org/10.1016/j.geoderma.2016.04.020

\section{Copyrights}

Copyright for this article is retained by the author(s), with first publication rights granted to the journal.

This is an open-access article distributed under the terms and conditions of the Creative Commons Attribution license (http://creativecommons.org/licenses/by/4.0/). 